\title{
PENGGUNAAN MODEL PEMBELAJARAN PBL UNTUK MENGEMBANGKAN KARAKTER BELAJAR MELALUI JURNAL ILMIAH
}

\author{
Pipit Putri Hariani MD1, Alfitriani Siregar ${ }^{2}$ \\ ${ }^{1}$ Program Studi Pendidikan Akuntasi, UMSU, Medan, Indonesia. \\ ${ }^{2}$ Program Studi Pendidikan Bahasa Inggris, UMSU, Medan, Indonesia \\ Korespondensi: Jl. Muchtar Basri No. 3 Medan. Email: pipitputrihariani@umsu.ac.id, \\ alfitrianisiregar@umsu.ac.id
}

\section{Article Info}

History of Article

Submited September 2018

Accepted March 2019

Published March 2019

\section{Key Word \\ Problem Based Learning, \\ Learning Character, \\ Scientific Journals.}

\section{Kata Kunci}

Problem Based Learning,

Karakter belajar, Jurnal

IImiah

\begin{abstract}
Tujuan penelitian ini untuk menganalisis penggunaan model problem based learning (PBL) dalam mengembangkan karakter belajar melalui jurnal ilmiah. Maka objek dalam penelitian ini yaitu 2 kelas Program studi Akutansi sebanyak 26 mahasiswa dan Bahasa Inggris sebanyak 28 mahasiswa. Teknik analisis data menggunakan; (a) Pengumpulan data, (b) Penyajian Data, (c) Reduksi Data, dan (d) Kesimpulan. Hasil dari penelitian ini terlihat pada proses pembelajaran dengan menggunakan model pembelajarn $\mathrm{PBL}$ dalam karakter belajar dapat memudahkan mahasiswa untuk menganalisis jurnal ilmiah pendidikan.
\end{abstract}

\begin{abstract}
Abstrak
The purpose of this study was to analyze the use of the problem based learning (PBL) model in developing learning characters through scientific journals. Then the objects in this study were 2 Accounting Study Program classes of 26 students and 28 English Language students. Data analysis techniques use; (a) Data collection, (b) Data Presentation, (c) Data Reduction, and (d) Conclusions. The results of this study are seen in the learning process using the PBL learning model in the character of learning which can make it easier for students to analyze scientific educational journals.
\end{abstract}

\section{Citation Info}

Hariani, P.P., dan Siregar, A., (2019). Penggunaan Model Pembelajaran PBL Untuk Mengembangkan Karakter Belajar Melalui Jurnal IImiah. In Biblio Couns: Jurnal Kajian Konseling dan Pendidikan, 2(01), 14-25. 


\section{PENDAHULUAN}

Sistem pendidikan tinggi diharapkan mampu menghasilkan lulusan yang berdaya saing tinggi. Sistem pembelajaran yang baik mampu memberikan pengalaman belajar kepada mahasiswa untuk membuka potensi dirinya dalam menginternalisasikan knowledge, skills dan attitudes serta pengalaman belajar. Menurut Oemar (2013: 57) Pembelajaran merupakan kombinasi yang tersusun meliputi unsur-unsur manusiawi, material, fasilitas, perlengkapan dan prosedur yang saling mempengaruhi agar tercapainya tujuan pembelajaran. Ini menjelaskan bahwa ada unsur yang harus membutuhkan satu dengan yang lainnya.

Permendikbud No. 49 Tahun 2014 tentang Standar Nasional Pendidikan Tinggi, telah mengharuskan sistem pembelajaran di perguruan tinggi berbasis pada capaian pembelajaran, serta proses pembelajarannya memiliki karakteristik yang mencerminkan sifat interaktif, holistik, integratif, saintifik, kontekstual, tematik, efektif, kolaboratif, pembelajaran berbasis maslah dan berpusat pada mahasiswa (students centred learning). Pendidikan hendaknya dapat mewujudkan pembelajaran yang berpusat pada mahasiswa (student centered) sehingga pembelajaran tersebut menjadi bermakna bagi mahasiswa. Pembelajaran yang bermakna diharapkan dapat mengembangkan pengetahuan mahasiswa dan kemampuan pemecahan masalahnya.

Pembelajaran di fakultas keguruan dan ilmu pendidikan (FKIP) ganjil pada program-program studi merupakan pembelajaran kurikulum secara Kerangka Kualifikasi Nasional Indonesia (KKNI) yang diperbaharui ditiap semesternya. Peraturan Presiden RI No. 8 Tahun 2012 tentang Kualifikasi KKNI memiliki pengetahuan faktual, bertanggung jawab atas pekerjaan sendiri, menyelesaikan masalah dan mampu mengaplikasikan dan memanfaatkan ilmu pengetahuan dengan menggunakan teknologi informasi dan komunikasi. Kegiatan yang dilakukan kepada mahasiswa merupakan suatu kegiatan yang bertujuan untuk memajukan perkembangan mereka. Kegiatan untuk memajuakan mahasiswa tersebut dapat dilakukan dengan kegiatan seperti melakukan ujian, tugas, pengamatan oleh dosen di ruang kelas dengan tatap muka atau di luar ruang kelas dengan menggunakan telepon pintar.

Perkembangan ilmu pengetahuan dan teknologi menggeser paradigma pembelajaran konvensional menuju model pembelajaran yang inovatif. Salah satu model pembelajaran inovatif yang adalah Problem Based Learning (PBL). PBL adalah model pembelajaran yang berlandaskan paham konstruktivis yang mengakomodasi keterlibatan mahasiswa dalam belajar dan menghandalkan dalam pemecahan masalah autentik.

Masalah pada mahasiswa FKIP sekarang ini, mereka membutuhkan model pembelajaran yang meringankan pembelajaran dengan melakukan kegiatan yang secara sistematis, dimana mereka harus menganalisis, meguji, berfikir, mengembangkan dan memberikan laporan kedalam Journal. Menurut rusman (2011: 229) mengatakan Pembelajaran Berbasis Masalah merupakan inovasi dalam pembelajaran karena didalam pembelajaran ini melibatkan untuk kemampuan berfikir mahasiswa betul-betul dioptimalisasikan melalui proses kerja kelompok atau tim yang 
sistematis, sehingga mahasiswa dapat memberdayakan, mengasah, menguji dan mengembangkan kemampuan berfikirnya secara berkesinambungan.

Pembelajaran KKNI sekarang ini, tidak hanya menghandalkan dalam mengklasifikasikan beberapa Journal yang telah dipublikasi secara ISSN (Internasional Standard Seri Number) atau ISBN (International Standard Book Number). Namun, mahasiswa harus mampu untuk membuat suatu mini research yang nantinya akan dipublikasikan kedalam Journal atau jurnal ilmiah. Menurut Ridwan (2008) Jurnal adalah penting terhadap sekurang-kurangnya sekelompok orang, isi dalam jurnal diperlukan hanya kurun waktu yang singkat, tetapi bermanfaat untuk beberapa tahun, dan bahkan untuk waktu yang sangat lama. Tujuan penerbitan jurnal ilmiah menurutnya adalah untuk memungkinkan para filsuf dan ilmuwan mengkomunikasikan ide dan pemikiran mereka kepada orang lain yang tertarik dalam subjek yang sama atau yang berdekatan.

Sedangkan menurut Gunawan (2012: 4) Jurnal ilmiah adalah sebuah publikasi yang diterbitkan secara berkala oleh suatu organisasi profesi atau institusi akademik yang memuat artikel-artikel yang merupakan produk pemikiran ilmiah secara empiris (artikel hasil penelitian) maupun secara logis (artikel hasil pemikiran) dalam bidang ilmu tertentu. Diantara tujuan dalam perkuliahan mahasiswa FKIP yaitu mampu membuat beberapa mini research atau hasil penelitian, namun tugas-tugas mereka hanya menentukan penilaian maksimal. Namun, tidak dalam publikasi atau penerbitan yang mengembangkan ide secara bentuk tulisan. Karena menurut Gunawan (2012: 5) Pemuatan artikel jenis bertujuan untuk membuka wacana diskusi dan kemungkinan penelitian baru, sekaligus untuk mengetahui apakah teori-teori atau pandanganpandangan yang terkait dengan masalah yang diteliti layak untuk untuk tetap diikuti atau harus ditinjau kembali.

Dalam PBL melalui Jurnal ilmiah dapat memotivasi belajar siswa diantaranya dalam skripsi mahasiswa terdahulu bahwa Diana (2012) tingkat motivasi belajar siswa di Madrasah Aliyah Negeri 2 Jepara tergolong tinggi dengan presentase rata-rata 81,93\% dan 81,56\% model PBL dapat membantu siswa untuk meningkatkan keterampilan berfikir kritis sehingga mampu merangsang motivasi siswa dalam belajar sejarah. Dimaksudkan PBL adalah model pembelajaran yang membutuhkan kemampuan berfikir kritis. Problem Based Learning (PBL) adalah metode pengajaran yang bercirikan adanya permasalahan nyata sebagai konteks untuk para peserta didik belajar berfikir kritis dan keterampilan memecahkan masalah, dan memperoleh pengetahuan (Duch,1995).

\section{KARAKTER BELAJAR}

Tuntutan belajar mahasiswa semankin ditingkatkan guna membentuk prestasi belajar mahasiswa pada tiap mata kuliah yang disajikan oleh dosen. Salah satu pembelajaran yang memungkinkan dapat dilakukan adalah pembelajaran yang berpusat pada mahasiswa atau disebut students centred learning. Tentang karakter belajar ini bahwa dalam suatu pembelajaran adanya suasana belajar akan semankin aktif bila terjadi pembelajaran secara dua arah yaitu dosen dan mahasiswa bisa berkomunikasi dengan Bahasa yang mudah dicernadan difahami, sehingga dalam 
mentransfer ilmu tidak ada batasan. Pembelajaran di kelas yang dapat meningkatkan karakter belajar mahasiswa, adalah;

a) Bertakwa kepada Tuhan

Karakter belajar mahasiswa bukan hanya dipandang pada kecakapan intelektual, digital, social dan akademik. Mahasiswa harus memiliki kecakapan hidup yang ditandai dengan keterampilan beriman, bertakwa, jujur, amanah sebagai balasan dalam menjalankan hidup sesuai perintah Tuhan.

b) Komunikasi

Dalam pembelajaran dikelas pentingnya komunikasi dalam kegiatan mentransfer ilmu untuk mendapatkan informasi baik secara lisan maupun tulisan. Namun, ada beberapa pengajar dalam menyampaikan informasi baik secara lisan, tetapi tidak secara tulisan.

Pada karakter belajar mahasiswa, dituntut untuk memahami mengelola dan menciptakan komunikasi yang efektif secra lisan, tulisan dan multimedia. Mahasiswa diberi kesempatan menggunakan kemampuan untuk mengutarakan ide-idenya, baik itu pada saat berdiskusi dengan teman maupun menyelesaikan masalah yang diberi oleh dosen. Kemudian berikanlah penerima informasi pada umpan balik atau feed back dalam pembelajaran dengan bertanya atau mengulang pembelajaran. Kegiatan ini dapat membentuk komunikasi mahasiswa untuk membimbing mereka dalam menyampaikan informasi dengan baik dan jelas, tidak berbelit-belit agar berkesan dan membuat sadar.

c) Kelompok belajar

Kegiatan pada karakter belajar didalam kelas secara kelompok dapat meningkatkan kerjasama yang saling bersinergi, beradaptasi dalam berbagai peran dan tanggung jawab, bekerja secara produktif antar teman, menempatkan empati pada tempatnya, menghormati perspektif yang berbeda antar teman.

d) Menyelesaikan Masalah

Pada karakter belajar mahasiswa dalam menggunakan kemampuan yang mereka miliki untuk berusaha menyelesaikan permasalahan yang dihadapi dengan mandiri, mereka juga harus mampu untuk menyusun dan mengungkapkan, menganalisa dalam menyelesaikan masalah.

e) Belajar Kritik

Proses belajar dalam menerima kritikan dapat membantu mahasiswa berfikir kritis bukan merespon yang bersifat arogan. Berfikir kritis merupakan respon mahasiswa untuk menerima akal/ ide-ide sebuah pemikiran yang diterima, dan respon tersebut melibatkan kemampuan untuk mengevaluasi secara sistematis. Untuk berfikir kritis dapat menghubungkan pembelajaran dengan masalahmasalah kontekstual yang ada dalam dikehidupan sehari-hari. Dalam mengasah kemampuan berfikir kritis dibutuhkan ketekunan, kedisplinan, motivasi, dan kemauan untuk menganalisis permasalahan.

f) Kreatif dan Inovatif

Untuk menciptakan mahasiswa yang mempunyai karakter belajar dengan keterampilan yang kreatif dan inovatif bukan dengan diintimidasi oleh dosen. Dosen sebagai fasilator dalam menampung hasil kreativitas dan inovasi yang 
dikembangkan oleh mahasiswa. Mereka dapat menciptakan kreativitas dengan menggunakan teknologi yang meningkatkan daya kreasi, inovasinya, menyenangkan dan berkarakter.

\section{MODEL PROBLEM BASED LEARNING}

Menurut Margaret (2011: 304) istilah masalah atau pemecahan masalah (problem solving) dalam kurikulum sekolah mengandung banyak makna dan saling bertentangan. Banyak latihan implisit dengan menyajikan pertanyaan dan merumuskan metode dan latihan-latihan integrative hanya menyajikan soal. Dan secara eksplisit menyajikan soal dan merumuskan prosedur serta menetapkan solusi. Dalam teori Vigotsky dalam Rusman (2011: 244) bahwa interaksi sosial dengan teman lain memacu terbentuknya ide baru dan memperkaya perkembangan intelektual mahasiswa. Dengan adanya pembelajaran PBL ini mengkaitkan informasi baru dengan struktur kognitif yang telah dimiliki oleh mahasiswa melalui kegiatan perkuliahan dalam interaksi sosial dengan teman lainnya. Dalam model PBL ini juga menekankan pemikiran seperti metakognnisi.

Komponen dalam metakognisi adalah:

1) Pengetahuan dan kesadaran tentang pemikiran diri sendiri;

2) Pengetahuan tentang kapan dan di mana mesti menggunakan strategi yang diperoleh.

Penggunaan model PBL ini nantinya akan dilakukan dari proses pembelajaran anatara mahasiswa dan dosen di dalam ruang kelas, sehingga penggunaan model PBL ini dapat menghasilkan jurnal ilmiah dosen dan mahasiswa yang berkelanjutan. Adapun kerangka teori tersebut;

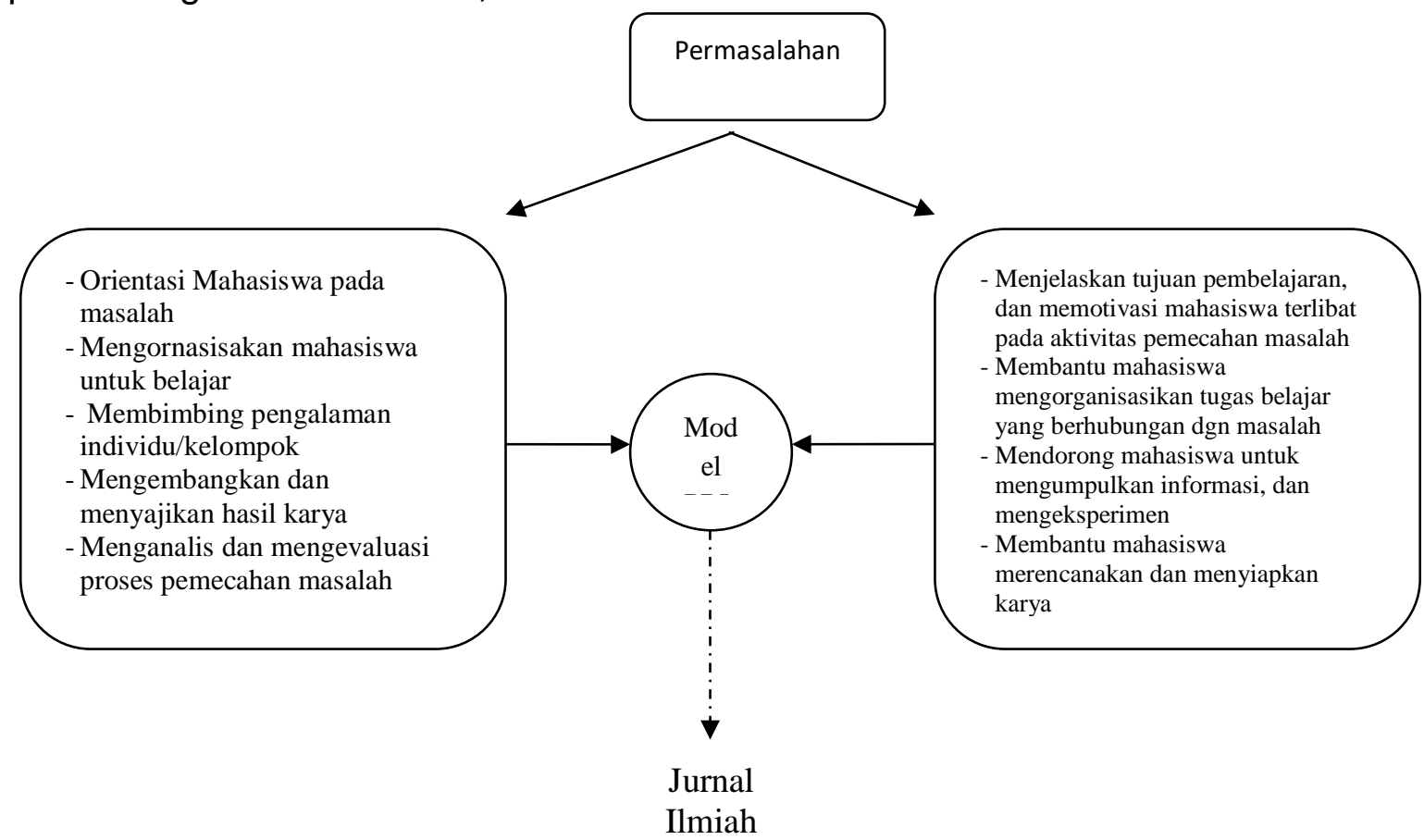

Gambar 1. alur rencana kerangka teori 
Problem based learning merupakan salah satu model pembelajaran yang dapat mengembangkan keterampilan berpikir rasional siswa, yaitu kemampuan menganalisis situasi, menerapkan pengetahuan yang mereka miliki dengan situasi baru, mengenal adanya perbedaan antara fakta dan pendapat, serta mengembangkan kemampuan siswa dalam membuat judgement secara objektif.

Menurut Boud dan Feletti (2011: 230) dalam Rusman mengatakan model PBL adalah inovasi yang paling siknifikan dalam pendidikan. Dan Margetson (2011: 230) menambahkan bahwa model PBL membantu untuk meningkatkan perkembangan keterampilan belajar sepanjang hayat dalam pola fikir yang terbuka, reflektif, kritis dan belajar aktif. Dan memfasilitasi kerberhasilan memecahkan masalah, komunikasi, kerja kelompok dan keterampilan interpersonal dengan lebih baik dibandingkan pendekatan yang lain.

PBL melibatkan mahasiswa dalam penyelidikan pilihan sendiri yang memungkinkan mereka menginterprestasikan dan menjelaskan fenomena dunia nyata dan membangun pemahamannya tentang fenomena itu. Menurut Rusman (2011: 243) mengemukakan langkah-langkah PBL sebagai berikut;

a. Tahap pertama: Orientasi mahasiswa pada masalah Dosen menjelaskan tujuan pembelajaran, menjelaskan logistik yang dibutuhkan, mengajukan fenomena atau demonstrasi atau cerita untuk memunculkan masalah, memotivasi mahasiswa untuk terlibat dalam pemecahan masalah.

b. Tahap dua: Mengorganisasi siswa untuk belajar. Dosen membantu mahasiswa untuk mendefinisikan dan mengorganisasikan tugas belajar yang berhubungan masalah tersebut.

c. Tahap tiga: Membimbing penyelidikan individual maupun kelompok. Dosen mendorong mahasiswa untuk mengumpulkan informasi yang sesuai, melaksanakan eksperimen, untuk mendapatkan penjelasan dan pemecahan masalah.

d. Tahap empat: Mengembangkan dan menyajikan hasil karya. Dosen membantu mahasiswa dalam merencanakan dan menyiapkan karya yang sesuai seperti laporan, video, dan model serta membantu mereka untuk berbagi tugas dengan temannya.

e. Tahap lima: Menganalisis dan mengevaluasi proses pemecahan masalah. Dosen membantu mahasiswa untuk melakukan refleksi atau evaluasi terhadap penyelidikan mereka dan proses-proses yang mereka gunakan.

\section{KETERAMPILAN PENULISAN JURNAL ILMIAH}

Jurnal ilmiah adalah artikel ilmiah (research article) yakni tulisan yang berisi laporan sistematis mengenai hasil kajian atau hasil penelitian yang disajikan bagi masyarakat ilmiah tertentu, yang merupakan audiens khusus dengan tujuan menyampaikan hasil kajian dan kontribusi penulis artikel kepada mereka untuk dipikirkan, dikaji kembali, dan diperdebatkan, baik secara lisan maupun secara tertulis.

Artikel yang terdapat dalam jurnal ilmiah memiliki banyak jenis, di antaranya adalah (1) artikel hasil penelitian, (2) artikel non-penelitian, (3) tinjauan buku (books review), dan (4) obituari (obituary), (5) laporan kasus, (6) ceramah, dan (7) editorial. 
Isi dan format artikel hasil penelitian dalam jurnal memiliki format umum yang relatif baku. Berikut ini disajikan uraian singkat tentang isi dan format atau sistematika penulisan artikel hasil penelitian yang lazim digunakan. Menurut Gunawan (2015: 8) artikel dan jurnal ilmiah pendidikan terdiri dari begian-bagian seperti; Judul, Pengarang dan Afiliasi Institusi, Abstrak, Pengantar, Metode, Hasil, Diskusi, Penghargaan dan Rujukan.

a. Judul, Nama Pengarang dan Afiliasi Institusi; judul artikel, hendaknya harus memenuhi hal-ha1 berikut: (1) informatif dan komprehensif, (2) mencerminkan isi artikel, (2) dapat menarik perhatian, (3) memuat variabel-variabel yang diteliti atau katakata kunci yang menggambarkan masalah yang, diteliti. Nama penulis dilengkapi dengan keterangan lembaga asal penulis yang disertai alamat lembaga, dan dilengkapi dengan emuil atau telpon untuk keperluan korespondensi.

b. Abstrak, Kata kunci; Abstrak berisi pernyataan ringkas dan padat tentang ideide yang paling penting. Abstrak berisi ringkasan dari inti suatu artikel secara komprehensif, yang memuat uraian masalah penelitian, tujuan penelitian, metode penelitian yang digunakan, dan hasil penelitian. Panjang abstrak kurang lebih 100 kata dan ditulis dalam satu paragraf. Kata kunci (keywords) menggambarkan ranah masalah yang diteliti dan istilah-istilah teknis yang berkaitan dengan penelitian yang dilaporkan, sebanyak kurang lebih 3-5 kata. Fungsi kata kunci digunakan untuk filling and searching, pengelompokkan, dan dokumentasi.

c. Pendahuluan; Umumnya memuat antara lain (1) permasalahan penelitian, yang mencakup uraian masalah atau alasan penelitian (latar belakang), pernyataan logis yang mengarah ke hipotesis atau tema pokok (2) cara pendekatan atau pemecahan masalah, (3) ' tujuan penelitian, (4) hasil yang diharapkan, dan (5) rangkuman kajian teoritik yang berkaitan dengan masalah yang diteliti. Dalam menulis kajian teoritik, sebaiknya gunakan acuan yang mutakhir dan relevan.

d. Metode; Bagian ini memuat unsur-unsur antara lain: (1) rancangan atau desain penelitian, (2) sasaran penelitian (populasi dan sampel atau subjek penelitian), (3) pengembangan instrumen dan teknik pengumpulan data, dan (4) teknik analisis data.

e. Hasil; Hasil penelitian tidak memuat pengujian hipotesis dan penggunaan statistik. Penyampaian hasil penelitian dapat dibantu dengan penggunaan tabel dan grafik.

f. Diskusi; Bagian pembahasan merupakan bagian terpenting dari keseluruhan isi artikel ilmiah. Bagian ini berisi ulasan atau pemaknaan hasil dan pembandingan dengan teori danfatau hasil penelitian sejenis. Pembahasan memuat jawabanjawan pertanyaan penelitian dan menunjukkan bagaimana temuan-temuan tersebut diperoleh, menginterpretasikan temuan, mengaitkan temuan penelitian ,.dengan struktur pengetahuan yang telah mapan, dan memunculkan teori-teori baru atau modifikasi dari teori yang telah ada.

g. Simpulan dan saran; Simpulan menyajikan ringkasan dan penegasan penulis mengenai temuan hasil penelitian yang berupa jawaban atas pertanyaan penelitian atau esensi dari hasil penelitian dan pembahasan.

h. Daftar rujukan; Daftar rujukan 'atau sering disebut juga dengan daftar pustaka ditulis dengan menggunakan pedoman umum. 


\section{PEMBAHASAN}

Pada awal pembelajaran perkuliahan seluruh dosen telah memberikan tugasan untuk membuat Mini Research sebagai tugas individu atau kelompok kepada Mahasiswa semester I. Mereka mendapat tugas untuk mencari dan membaca jurnaljurnal yang berkaitan dengan Mata Kuliah. Peneliti mulai mencari gambaran permasalahan bahwa tidak adanya bahan rujukan yang jelas untuk mereka dalam membuat tugasan, selain rujukan pada susunan tugas Mini Research yang diberikan Dosen.

Peneliti menganalisis penerapan pembelajaran dengan melakukan pembelajaran berbasis masalah melalu penulisan jurnal. Menurut Rusman (2011: 243) dalam mengemukakan langkah-langkah PBL sebagai berikut;

Tahap pertama: Orientasi mahasiswa pada masalah Dosen menjelaskan tujuan pembelajaran, menjelaskan logistik yang dibutuhkan, mengajukan fenomena atau demonstrasi atau cerita untuk memunculkan masalah, memotivasi mahasiswa untuk terlibat dalam pemecahan masalah. Dalam hal ini mahasiswa telah diberikan penjelasan sebelumnya oleh dosen pada tatap muka pertama sesuai denga RPS mata kuliah.

Tahap dua: Mengorganisasi siswa untuk belajar. Dosen membantu mahasiswa untuk mendefinisikan dan mengorganisasikan tugas belajar yang berhubungan masalah tersebut. Pada tahapan ini peneliti membantu dosen untuk menjelaskan pembelajaran dengan menggunakan pembelajaran berbasis masalah melalui jurnal pada mata kuliah.

Dalam hal ini penulisan jurnal yang harus diketahui oleh mahasiswa dapat dilakukan pada langkah-langkah berikut; Menurut Gunawan (2015: 8) susunan penulisannya adalah Judul, Abstrak, Pendahuluan, Metode, Hasil, Diskusi, Kesimpulan dan saran, Daftar rujukan. Pada penulisan pendahuluan ada latar belakang yang perlu dikaji yaitu Menurut Jejen (2016: 20)

a) Landasan Historia merupakan paparan tentang sejarah yang terkait pada focus kajian, misalnya tentang sejarah kurikulum, sejarah peradaban Islam.

b) Landasan Yuridis merupakan kajian perundangan yang memuat tentang UUD, perda atau permen dengan fokus kajian

c) Landasan Normatif merupakan kutipan ayat Al quran dan hadis yang terkait pada fokus kajian.

d) Landasan teoritis merupakan kutipan pendapat minimal tiga pakar terkait fokus kajian, pendapat pakar yang dikutip bias setuju atau mendukung teori atau konsep kajian.

e) Landasan factual merupakan kutipan berita yang menunjukkan masalah-masalah yang terkait pada penelitian. Misalnya pemunculan sejumlah masalah nyata di masyarakat menjadi bukti penting pada penelitian

Tahap tiga: Membimbing penyelidikan individual maupun kelompok. Dosen mendorong mahasiswa untuk mengumpulkan informasi yang sesuai, melaksanakan eksperimen, untuk mendapatkan penjelasan dan pemecahan masalah. Tahapan ini dilakukan FGD dengan berdiskusi antara dosen dan mahasiswa membahas masalah 
pembelajaran maupun penulisan jurnal yang baik. Gambaran dokumentasi mahasiswa melakukan FGD, sebagai berikut;

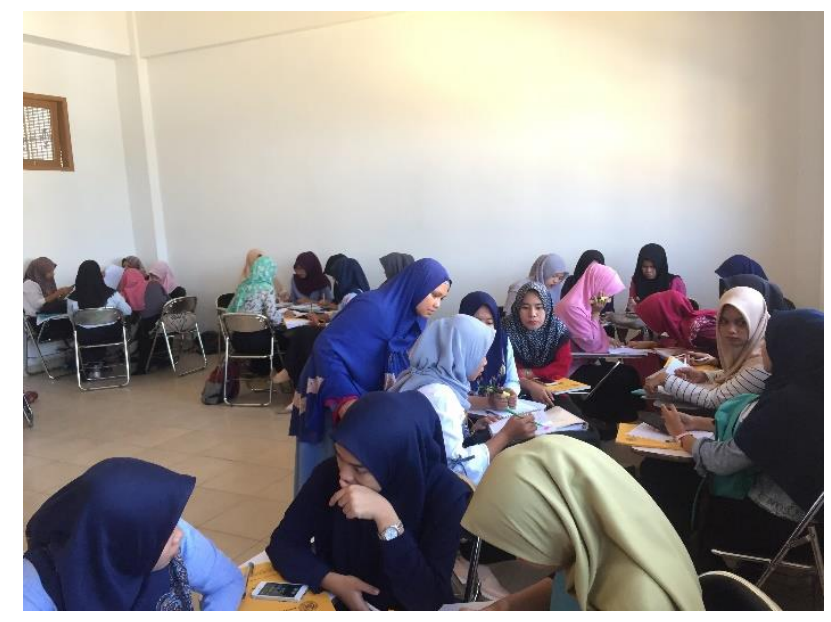

\section{Gambar 2. Mahasiswa berdiskusi kelompok}

Terlihat pada gambar diatas mahasiswa sedang melakukan diskusi kelompok dengan membahas masalah-masalah dalam penulisan jurnal. Didalam kelas ini juga dibentuk tatanan duduk mahasiswa berfokus pada Formasi Corak Tim, yaitu mengelompokkan meja-meja setengah lingkaran atau oblong di ruang kelas agar memungkinkan dosen untuk melakukan interaksi dengan mahasiswa. Dosen dapat meletakkan kursi-kursi mengelilingi meja-meja untuk susunan yang paling akrab. Jika Dosen melakukan interaksi kepada mahasiswa, mereka harus memutar kursi mereka melingkar menghadap ke depan ruang kelas untuk melihat dosen, atau papan tulis atau layar. Seperti gambar dibawah ini;
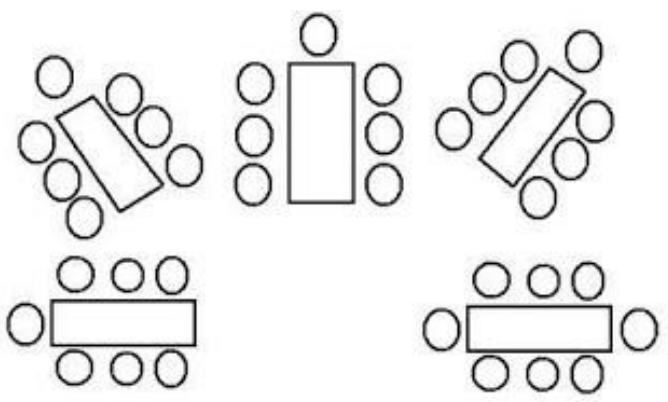

\section{Gambar 3. Formasi corak tim}

Tatanan kursi seperti gambar diatas dapat membantu mahasiswa dengan berdiskusi langsung tanpa ada gangguan dari kelompok lain. Dosen juga memudahkan untuk berkomunikasi dengan kelompok mahasiswa.

Tahap empat: Mengembangkan dan menyajikan hasil karya. Dosen membantu mahasiswa dalam merencanakan dan menyiapkan karya yang sesuai seperti laporan, video, dan model serta membantu mereka untuk berbagi tugas dengan temannya. Dari tahapan ini mahasiswa masing-masih memberikan hasil tugasan mereka kepada 
dosen. Hasil tugasan ini dapat dinilai keberhasilan mereka dalam memahami penulisan jurnal.

Tabel 1. Nilai dalam menganalisa jurnal pada kemampuan pengetahuan hasil tugas

\begin{tabular}{|l|l|l|l|l|l|l|l|l|l|l|}
\hline & & & & & & & & & & \\
Mahasiswa Semester I & $\mathbf{1}^{*}$ & $\mathbf{2}^{*}$ & $\mathbf{3}^{*}$ & $\mathbf{4}^{*}$ & $\mathbf{5}^{*}$ & $\mathbf{6}^{*}$ & $\mathbf{7}^{*}$ & $\mathbf{8}^{*}$ & $\mathbf{9}^{*}$ & $\mathbf{1 0}^{*}$ \\
\hline Mahasiswa Akuntansi & 26 & 24 & 23 & 23 & 23 & 24 & 23 & 26 & 169,25 & $65 \%$ \\
\hline Mahasiswa Bahasa Inggris & 28 & 28 & 25 & 25 & 25 & 25 & 25 & 28 & 184,5 & $71 \%$ \\
\hline \multicolumn{10}{|c|}{ TOTAL }
\end{tabular}

Keterangan:

1*Pendahuluan

2* Abstrak

3* Pendahuluan

$4^{*}$ Metode

5* Hasil

6* Diskusi

$7^{*}$ Kesimpulan

8* Daftar Rujukan

9* Total

10* Rata-rata

Terlihat pada table diatas bahwa peningkatan dalam menganalis jurnal pendidikan cukup tinggi. Dapat diartikan kemampuan pengetahuan mahasiswa terlihat dari rata-rata tes kemampuan pengetahuan dengan berdiskusi. Dokumentasi dibawah ini juga menjelaskan beberapa mahasiswa mengumpulkan tugas hasil laporan mereka kepada dosen.

Tahap lima: Menganalisis dan mengevaluasi proses pemecahan masalah. Dosen membantu mahasiswa untuk melakukan refleksi atau evaluasi terhadap penyelidikan mereka dan proses-proses yang mereka gunakan. Tahapan ini dilakukan refleksi kepada mahasiswa untuk merangkum penjelasan dosen tentang penulisan jurnal, mahasiswa aktif dalam pembelajaran yang diberikan dosen, mereka lebih mudah dalam memahami tugas-tugas mereka dengan berdiskusi.

Mahasiswa juga antusias dengan kegiatan pembelajaran yang digunakan dalam model pembelajaran berbasis masalah. Mereka lebih fokus belajar, memotivasi belajar mereka dengan cara berfikir dan memecahkan masalah. Menurut Rusman (2011: 232) didalam karakteristik pembelajaran berbasis masalah ada beberapa yang harus diperhatikan;

a) Permasalahan pertama adalah dalam belajar, Mahasiswa mampu belajar namun ketika diberi tugasan baru harus dikomunikasikan antara dosen dan mahasiswa mengenai pemahaman mereka. 
b) Permasalahan membutuhkan perspektif ganda, Ide dari beberapa orang mahasiswa harus dirundingkan terlebih dahulu agar mendapat satu ide pokok dalam pembahasan.

c) Pembelajaran berbasis masalah melibatkan evaluasi, mahaiswa bukan hanya ditugaskan untuk mencari tugas namun menghasilkan karya atau laporan akhir sebagai tugas.

Secara sedehana tahapan problem based learning menimbulkan dampak yang positif bagi mahasiswa adalah sebagai berikut;

1) Mahasiswa semangkin aktif, ini membuktikan adanya model pembelajaran $\mathrm{PBL}$ ini mereka aktif mencari ilmu sendiri dari berbagai sumber ilmu,

2) Karakter belajar yang disiplin, mereka mampu membuat perencanaan belajar, penyelesaian tugas, dan kegiatan belajar berkelompok, sehingga pada saatnya harus menghadapi evaluasi tidak terlalu kerepotan, dan

3) Belajar dengan kritis, mereka yang kritis tidak akan menelan mentah-mentah sesuatu pendapat yang didengar atau diterimanya, tetapi akan menimbulkan pertanyaan internal. Hasil dari penelitian ini terlihat pada proses pembelajaran dengan menggunakan model pembelajarn PBL dapat memudahkan mahasiswa untuk menganalisis jurnal ilmiah pendidikan.

\section{KESIMPULAN}

Penelitian ini dilakukan dengan tahapan prosedur model pembelajaran berbasis masalah. Ada 5 tahapan model pembelajaran berbasis masalah dilakukan secara metode kualitatif di FKIP UMSU. Dan tahapan ini menghasilkan mahasiswa yang berkarakter disiplin dalam belajar di kelas dengan melakukan diskusi kritis. Diskusi kritis bukan menanggapi pernyataan secara egois sendiri tetapi menanggapi, menyimak dan memberikan solusi antara teman dan teman atau mahasiswa dan dosen dikelas. Pembelajaran ini dapat dilakukan secara berbeda di mata kuliah yang lain, karena pembelajaran ini merupakan pembelajaran yang bermakna pada mahasiswa atau student centered learning.

\section{REFERENSI}

Ades, Sanjaya. 2011. Model-model Pembelajaran. Bumi Aksara. Jakarta

Arikunto. 2010. Prosedur Penelitian: Suatu Pendekatan Praktek. Jakarta: Rineka Cipta.

Gredler, Margaret E. 2011. Learning and Instruction: Teori dan Aplikasi. Jakarta: Kencana

Rusman. 2011. Model-Model Pembelajaran: mengembangkan profesionalisme guru. Jakarta: Rajawali

Sugiyono. 2012. Metode Penelitian Kuantitatif Kualitatif dan R\&D. Bandung: Alfabeta. 
Biblio Couns : Jurnal Kajian Konseling dan Pendidikan | Vol. 2 No. 1 Maret 2019

Suryoputro,Gunawan., Sugeng Riadi., \&Ali Sya'ban. 2012. Menulis Artikel Untuk Jurnal IImiah. Jakarta: UHAMKA PRESS

Tirtarahardja, Prof Umar. 2005. Pengantar Pendidikan. Jakarta: Rineka Cipta 